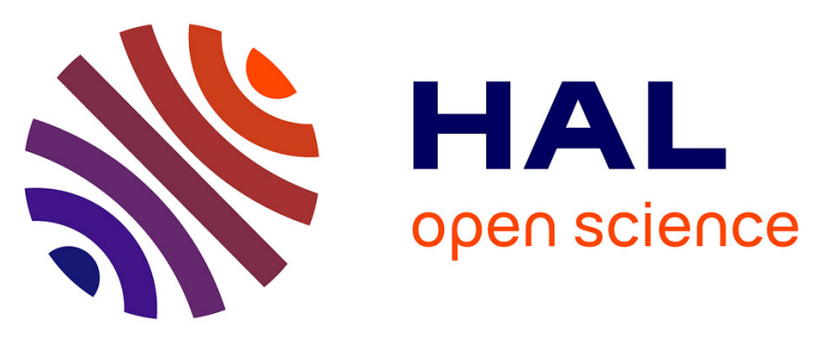

\title{
Corrosion and Hydrogen Permeation in H2S Environments with O2 Contamination, 1: Tests on Pure Iron at High H2S Concentration
}

Martien Duvall Deffo Ayagou, C. Mendibide, Claude Duret-Thual, Jean Kittel, Khawla Belkhadiri, Mai Tran, Eliane Sutter, Bernard Tribollet, Nicolas Ferrando

\section{To cite this version:}

Martien Duvall Deffo Ayagou, C. Mendibide, Claude Duret-Thual, Jean Kittel, Khawla Belkhadiri, et al.. Corrosion and Hydrogen Permeation in H2S Environments with O2 Contamination, 1: Tests on Pure Iron at High H2S Concentration. Corrosion, 2018, 74 (11), pp.1192 - 1202. 10.5006/2893 . hal-01888527

\section{HAL Id: hal-01888527 \\ https: / hal.sorbonne-universite.fr/hal-01888527}

Submitted on 30 Nov 2018

HAL is a multi-disciplinary open access archive for the deposit and dissemination of scientific research documents, whether they are published or not. The documents may come from teaching and research institutions in France or abroad, or from public or private research centers.
L'archive ouverte pluridisciplinaire HAL, est destinée au dépôt et à la diffusion de documents scientifiques de niveau recherche, publiés ou non, émanant des établissements d'enseignement et de recherche français ou étrangers, des laboratoires publics ou privés. 


\title{
Corrosion and Hydrogen Permeation in $\mathrm{H}_{2} \mathrm{~S}$ Environments with $\mathrm{O}_{2}$ Contamination, 1: Tests on Pure Iron at High $\mathrm{H}_{2} \mathrm{~S}$ Concentration
}

\author{
Martien Duvall Deffo Ayagou, ${ }^{*}$ C. Mendibide, ${ }^{*}$ Claude Duret-Thual,${ }^{*}$ Jean Kittel, ${ }^{\ddagger * * *}$ Khawla Belkhadiri, ${ }^{* *}$ Thi Tuyet Mai \\ Tran, ${ }^{* * *}$ Eliane Sutter, ${ }^{* * *}$ Bernard Tribollet, ${ }^{* * *}$ and Nicolas Ferrando
}

†Corresponding author. E-mail: jean.kittel@ifpen.fr.

*Institut de la Corrosion Site de Saint-Etienne, ZA du parc secteur Gampille, Fraisses F-42490, France.

** IFP Energies Nouvelles, Rond point de l'échangeur de Solaize BP3, Solaize F-69360, France.

${ }^{* * *}$ Sorbonne Université, CNRS, Laboratoire Interfaces et Systèmes Electrochimiques (LISE), Paris F-75005, France.

**** IFP Energies Nouvelles, 1 et 4 avenue de bois préau, Rueil-Malmaison F-92852, France.

\begin{abstract}
Materials selection in the oil and gas industry relies on engineering standards, such as NACE TM0177 and NACE TM0284, which stipulate that oxygen pollution should be avoided during materials testing in $\mathrm{H}_{2} \mathrm{~S}$-containing media. In this paper, we explore the manner in which traces of oxygen can modify the test solution chemistry and the corrosion of/ hydrogen permeation across iron membranes in $\mathrm{H}_{2} \mathrm{~S}$-containing solutions. Oxygen pollution is shown to strongly influence solution chemistry, through the introduction of sulfur-oxygen reaction products resulting in bulk acidification. Weight loss, electrochemical methods, and solution chemistry measurements conclude that iron corrosion rates in the presence of oxygen pollution are doubled, when compared against the control system (without oxygen pollution). Unexpectedly, despite a lower $\mathrm{pH}$ and higher corrosion rates in the oxygen-polluted $\mathrm{H}_{2} \mathrm{~S}$-containing solutions, the hydrogen permeation rate decreases monotonically, relative to the control. We discuss how this observation is most likely related to a disruption of sulfur adsorbates involved in hydrogen entry promotion.
\end{abstract}

Key words: hydrogen permeation, hydrogen sulfide, hydrogen-induced cracking, sulfide stress cracking

\section{INTRODUCTION}

Materials used in oil and gas industries can be exposed to sour environments containing hydrogen sulfide $\left(\mathrm{H}_{2} \mathrm{~S}\right)$, which is corrosive and known to promote hydrogen entry into steels. This may lead to several types of failures such as hydrogeninduced cracking, sulfide stress cracking, or stress-oriented hydrogen-induced cracking. Corrosion and hydrogen embrittlement of steels in $\mathrm{H}_{2} \mathrm{~S}$-containing environments has been studied for several decades. Standard test methods have been developed for the selection and the qualification of steels for use in $\mathrm{H}_{2} \mathrm{~S}$-containing environments, such as NACE TM 0177 and TM $0284 .{ }^{1-2}$ These standards strongly recommend to avoid any oxygen ingress in test environments. For instance, it is stated that "obtaining and maintaining an environment with minimum dissolved $\mathrm{O}_{2}$ contamination is considered very important." It is also mentioned that, " $\mathrm{O}_{2}$ contamination may induce an increase of the corrosion rate and reduce hydrogen evolution and hydrogen entry into the steel", although "systematic studies of the parameters affecting these phenomena have not been reported in the literature." 
There are many different ways by which oxygen can pollute a test medium, such as an incorrect or insufficient deaeration of the initial test solution, a poor sealing of test reactors, the use of plastic tubing permeable to oxygen, and a multitude of operations during the test (solution sampling, $\mathrm{pH}$ adjustment, etc.). For the present study, we have investigated the impact of a continuous ingress of small amounts of gaseous $\mathrm{O}_{2}$ in a test solution, during a corrosion test with aqueous $\mathrm{H}_{2} \mathrm{~S}$. Song, et al., ${ }^{3}$ have reported that a solution continuously bubbled with a mixture of $\mathrm{H}_{2} \mathrm{~S}$ and $\mathrm{O}_{2}$ continuously acidifies and does not rise back to neutrality even after purging out $\mathrm{H}_{2} \mathrm{~S}$ with an inert gas (argon, nitrogen). Such an experimental finding is in good agreement with the reaction pathway proposed by Crolet, et al., ${ }^{4}$ showing that $\mathrm{O}_{2}$ and $\mathrm{H}_{2} \mathrm{~S}$ can react to form dissolved thiosulfate or tetrathionate. In both cases, $\mathrm{H}^{+}$ions are also produced, resulting in a decrease in $\mathrm{pH}$. The produced sulfur-oxygen (S-O) compounds could, then, modify the kinetics and corrosion mechanisms. This was confirmed by Kuo, et al., who showed that the presence of thiosulfate in chlorinated $\mathrm{H}_{2} \mathrm{~S}$ medium significantly increased the corrosion rate of immersed steels. ${ }^{5}$ These authors used anodic polarization experiments and microscopic observations to conclude that thiosulfate participates in electrochemical reactions. It is also well known that $\mathrm{H}_{2} \mathrm{~S}$ promotes hydrogen entry in steels via sulfur adsorbates. ${ }^{6-8}$ Metal surface reactions with $\mathrm{O}_{2}$ or with $\mathrm{O}_{2}-\mathrm{H}_{2} \mathrm{~S}$ reaction products could interact with the hydrogen entry process. Some authors have proposed to use thiosulfate solutions to replace $\mathrm{H}_{2} \mathrm{~S}$ in cracking experiments. ${ }^{9-10}$ Indeed, they suggest that thiosulfate reduction at the metal surface could result in the formation of $\mathrm{H}_{2} \mathrm{~S}$, resulting in an increase of hydrogen permeation.

In summary, oxygen traces in $\mathrm{H}_{2} \mathrm{~S}$-containing environment could modify the system in three distinct areas:

- changing the composition of the corrosive environment;

- modifying the corrosion rate and the nature of corrosion deposits;

- interacting with $\mathrm{H}_{2} \mathrm{~S}$ adsorbates and changing the efficiency of hydrogen entry.

This series of papers aims at improving the understanding of corrosion mechanisms and hydrogen entry into steels in $\mathrm{H}_{2} \mathrm{~S}-$ containing environment polluted by traces of oxygen. In this first part, a model system is used. It consists of pure iron in the annealed condition, exposed to $35 \mathrm{~g} / \mathrm{L} \mathrm{NaCl}$ saturated with $\mathrm{H}_{2} \mathrm{~S}$ at a partial pressure close to $0.1 \mathrm{MPa}$. A gas supply system permits well-controlled $\mathrm{O}_{2}$ entry in the test cell, at a partial pressure of $1 \mathrm{kPa}$ to $1.5 \mathrm{kPa}$, thus corresponding to 500 ppbw (parts per billion by weight) dissolved $\mathrm{O}_{2}$ at equilibrium. Both corrosion and hydrogen uptake tests are conducted using a classic two-chamber hydrogen permeation cell. At the entry side, electrochemical impedance spectroscopy (EIS) is used to evaluate the corrosion behavior of the iron membrane in the $\mathrm{H}_{2} \mathrm{~S}$ medium. At the exit side, hydrogen permeation is measured by anodic extraction. Chemical analysis of the test solution is also performed in order to identify reaction products between $\mathrm{O}_{2}$ and $\mathrm{H}_{2} \mathrm{~S}$.

\section{EXPERIMENTAL PROCEDURE}

\section{Test Solution}

In order to keep the system as simple as possible, tests were performed in solutions containing $35 \mathrm{~g} / \mathrm{L} \mathrm{NaCl}$ without added acids or buffering species. Continuous bubbling of gases into the solution was maintained during all experiments. In order to control the quantity of oxygen introduced in the test cell, two separate gas lines with mass flow controllers were used. The first gas line consists of a pure $\mathrm{H}_{2} \mathrm{~S}$ or $\mathrm{H}_{2} \mathrm{~S} / \mathrm{N}_{2}$ mix, with a typical flow rate of $17 \mathrm{~mL} / \mathrm{min}$ to $20 \mathrm{~mL} / \mathrm{min}$. The second gas line is fed with $\mathrm{O}_{2} / \mathrm{N}_{2}$ at a typical $\mathrm{O}_{2}$ concentration of $10 \%$, and is used at a flow rate comprised between $0 \mathrm{~mL} / \mathrm{min}$ and $3 \mathrm{~mL} / \mathrm{min}$. Gas lines and several valves (fabricated from 316L stainless steel) manage the gas supply into the cell. Gases are homogenized in a spiral gas line of approximately $1 \mathrm{~m}$ before bubbling into the test solution and the oxygen content in the gas line immediately before entering into the test cell is confirmed using an HACH 410 Orbisphere ${ }^{\mathrm{TM}}$ probe. With this system, $\mathrm{O}_{2}$ partial pressure in the gas entering into the test cell can then be controlled precisely between zero and a few kilopascals.

The theoretical amounts of dissolved $\mathrm{O}_{2}$ and $\mathrm{H}_{2} \mathrm{~S}$ are given by Henry's law, i.e., their concentration $\left(\mathrm{C}_{\mathrm{i}}\right)$ is equal to their partial pressure $\left(\mathrm{P}_{\mathrm{i}}\right)$ times the Henry's constant $\left(\mathrm{K}_{\mathrm{i}}\right)$ :

$$
\mathrm{C}_{\mathrm{i}}=\mathrm{K}_{\mathrm{i}} \mathrm{P}_{\mathrm{i}}
$$

The Henry's constant values for $\mathrm{H}_{2} \mathrm{~S}$ and $\mathrm{O}_{2}$ at $24^{\circ} \mathrm{C}$ are, respectively, $1 \mathrm{~mol} / \mathrm{L} / \mathrm{Mpa}$ and $1.3 \times 10^{-2} \mathrm{~mol} / \mathrm{L} / \mathrm{MPa}{ }^{11-12}$ The range of $\mathrm{P}_{\mathrm{O} 2}$, comprised between 0 and a few kilopascals, thus corresponds approximately to 0 ppbw to $500 \mathrm{ppbw}$ dissolved $\mathrm{O}_{2}$ at saturation. In this paper, two gas compositions were used: pure $\mathrm{H}_{2} \mathrm{~S}$ and a mix of $\mathrm{H}_{2} \mathrm{~S}(87.5 \%), \mathrm{N}_{2}$ $(11.25 \%)$, and $\mathrm{O}_{2}(1.25 \%) \cdot 1.25 \% \mathrm{O}_{2}$ at $24^{\circ} \mathrm{C}$ corresponds to 500 ppbw dissolved at saturation. Because the recent 
revisions of NACE TM0177 and NACE TM0284 mention some $\mathrm{O}_{2}$ limits expressed in mass ppb, this unit will be used in the paper, though the parameter that was indeed controlled was $\mathrm{O}_{2}$ partial pressure.

All experiments were performed at $24^{\circ} \mathrm{C} \pm 2^{\circ} \mathrm{C}$.

\section{Electrochemical Measurements}

Permeation measurements were performed using the electrochemical technique with a Devanathan-Stachurski-type jacketed cell. ${ }^{13}$ The experimental setup was made of twin cells separated by the iron membrane, with one side exposed to the corrosive $\mathrm{H}_{2} \mathrm{~S}$ medium (entry side) and the other side (covered by $\mathrm{Pd}$ ) exposed to deaerated $0.1 \mathrm{M} \mathrm{NaOH}$ (exit side). We highlight that the $35 \mathrm{~g} / \mathrm{L}$ test solution, for the entry side, was first purged with argon gas ( $16 \mathrm{~h}$ to $20 \mathrm{~h}$ ), before a $6 \mathrm{~h}$ purging of the $\mathrm{H}_{2} \mathrm{~S}$ or $\mathrm{H}_{2} \mathrm{~S}-\mathrm{O}_{2}$ gas mixture. The cells' jackets permitted the circulation of thermostatically controlled water, and thus maintained the solution temperature at $24^{\circ} \mathrm{C} \pm 2^{\circ} \mathrm{C}$ throughout the testing period.

The membrane was $99.5 \%$ iron, with composition given in Table 1 . After machining, the permeation membranes were heat treated under vacuum at $900^{\circ} \mathrm{C}$ for $30 \mathrm{~min}$, in order to reduce metallurgical defects such as dislocations. The sample membrane thickness was $0.5 \mathrm{~mm}$ and the exposed surface was $16 \mathrm{~cm}^{2}$ on both sides. The exit face was covered by palladium following well-established procedures. ${ }^{14}$ Under such conditions of iron membrane thickness and environment, it is considered that permeation is mostly governed by reactions at the entry face, minimizing the impact of bulk diffusion of hydrogen. ${ }^{7,15}$ The charging side of the iron membrane was used as a working electrode during EIS measurements, with an $\mathrm{Ag} / \mathrm{AgCl}$ reference electrode and a platinum mesh as auxiliary electrode. A perturbation of $\pm 10 \mathrm{mV}$ amplitude around the corrosion potential was applied with a range of frequency of $10 \mathrm{kHz}$ to $1 \mathrm{mHz}$. Each EIS measurement was preceded by an open-circuit potential (OCP) measurement of about $2 \mathrm{~h}$. OCP and EIS measurements were repeated over the total experiment period, which lasted between 3 and 4 weeks. The exit surface of the membrane was held in a deoxygenated $0.1 \mathrm{~mol} / \mathrm{L} \mathrm{NaOH}$ solution and, as a working electrode, was polarized to $+250 \mathrm{mV}_{\mathrm{Hg} / \mathrm{HgO}}(1 \mathrm{M} \mathrm{KOH})$ reference electrode. With the three-electrode system completed with an immersed platinum mesh, the resulting current at the exit surface provided a direct measurement of the hydrogen flux across the iron membrane. Specific precautions (instrument ground in floating mode) were taken to avoid interferences between electrochemical measurements performed simultaneously on both sides of the iron membrane. In addition to the permeation membrane, weight-loss coupons $(0.9 \mathrm{~cm} \times 0.9 \mathrm{~cm} \times 0.05$ $\mathrm{cm}$ ) were also introduced into the entry side chamber. These coupons were used for weight-loss corrosion rate evaluation, as well as surface analysis by scanning electronic microscopy (SEM), and x-ray diffraction (XRD). Considering the surface areas of the permeation membrane and iron coupons, the ratio between test solution volume and exposed iron surface area was approximately $20 \mathrm{~mL} / \mathrm{cm}^{2}$.

During each test, the charging solution was periodically sampled and analyzed by ionic chromatography (IC) to determine the S-O species concentrations. Sampling was performed through a septum with a syringe equipped with a filter, in order to remove FeS particles. Argon purging was then immediately applied to water aliquots in order to remove dissolved $\mathrm{H}_{2} \mathrm{~S}$ and to retain only nonvolatile sulfur-containing compounds. The removal of $\mathrm{H}_{2} \mathrm{~S}$ from these aliquots was required prior to IC measurement. The total volume of solution sampled represents less than $20 \mathrm{~mL}$ compared to $400 \mathrm{~mL}$ in total. Solution replenishment was not considered necessary. At the end of the test, the total sulfur content (exclusive of $\mathrm{H}_{2} \mathrm{~S}$ ) in the charging solution was analyzed by inductively coupled plasma emission spectroscopy (ICPES).

\section{RESULTS}

\section{Control of $\mathrm{O}_{2}$ Partial Pressure}

Preliminary tests were performed using $\mathrm{CO}_{2}$ instead of $\mathrm{H}_{2} \mathrm{~S}$ in the acid gas line, and $\mathrm{N}_{2} / \mathrm{O}_{2}$ in the oxygen line, in order to check that dissolved $\mathrm{O}_{2}$ could be controlled at various levels between a few tens of parts per billion by weight and 500 ppbw. Such verification could not be performed with $\mathrm{H}_{2} \mathrm{~S}$, because reactions between $\mathrm{O}_{2}$ and $\mathrm{H}_{2} \mathrm{~S}$ are expected, resulting in an $\mathrm{O}_{2}$ concentration that would be far less than its solubility equilibrium. Different levels of $\mathrm{O}_{2}$ partial pressure were then obtained by selecting different flow rates for both gas lines. Dissolved $\mathrm{O}_{2}$ concentration was measured with the $\mathrm{O}_{2}$ probe and compared with theoretical value at equilibrium. The results illustrated in Figure 1 show that a stable $\mathrm{O}_{2}$ content can be achieved and maintained. Experimental values were very close to theoretical values calculated from mass flow rates settings and Henry's law, also shown in Figure 1.

From these tests, our gas mixing system allowed a control of oxygen content at least up to $1.3 \mathrm{kPa}$, corresponding to approximately $500 \mathrm{ppbw}$ dissolved $\mathrm{O}_{2}$. This system was then used with $\mathrm{H}_{2} \mathrm{~S}$. No additional $\mathrm{O}_{2}$ measurements were performed with $\mathrm{H}_{2} \mathrm{~S}$, because $\mathrm{O}_{2}-\mathrm{H}_{2} \mathrm{~S}$ reactions were likely to occur quickly in water. In addition, $\mathrm{H}_{2} \mathrm{~S}$ could also deteriorate the oxygen probe. It was also carefully checked that, for reference corrosion tests without oxygen, i.e., pure 
$\mathrm{H}_{2} \mathrm{~S}$, the residual $\mathrm{O}_{2}$ concentration was well below 5 ppbw. Hence, test conditions with $\mathrm{O}_{2}$ pollution correspond to a wellcontrolled $\mathrm{PO}_{2}$ in the gas phase bubbling into the test solution, although the effective value of dissolved $\mathrm{O}_{2}$ is not known, as a result of $\mathrm{H}_{2} \mathrm{~S}-\mathrm{O}_{2}$ reactions. One must then keep in mind that $\mathrm{O}_{2}$ values in parts per billion by weight given in this paper thus correspond to what would be observed in the test solution in the absence of reactive species (e.g., $\mathrm{H}_{2} \mathrm{~S}$, but also dissolved iron that can precipitate with $\mathrm{O}_{2}$ ). The same remark holds for NACE TM0284 and NACE TM0177, where maximum $\mathrm{O}_{2}$ content is given in parts per billion by weight.

\section{Impact of Oxygen on Corrosive Medium}

In order to determine the impact of $\mathrm{O}_{2}$ contamination on the test solution, several tests were conducted with continuous $\mathrm{pH}$ measurement and periodic sampling of test solutions used for chemical analysis. The $\mathrm{pH}$ trends of test solutions with or without oxygen are shown in Figure 2. These $\mathrm{pH}$ measurements were performed during a permeation experiment, i.e., with iron coupons in the test solution.

In the beginning of both tests, $\mathrm{pH}$ is close to 3.9 , corresponding to $\mathrm{H}_{2} \mathrm{~S}$-saturated water at $0.1 \mathrm{MPa}$. As expected, the $\mathrm{pH}$ then increases up to 4.3 with time, corresponding to $\mathrm{FeS}$ saturation. Once saturation is reached, no change of $\mathrm{pH}$ is observed for the test without $\mathrm{O}_{2}(\mathrm{pH}$ at end $=4.4)$. The test solution treated with both $\mathrm{H}_{2} \mathrm{~S}$ and $\mathrm{O}_{2}$ experiences a short initial rise in $\mathrm{pH}$, followed by a continuous decrease in $\mathrm{pH}$, by an order of magnitude, until the end of the test $(\mathrm{pH}$ at end $=$ 3.2). It must be mentioned that for this test, measurements of $\mathrm{O}_{2}$ concentration in the gas phase at the outlet of the test cell were periodically performed. We note that $\mathrm{O}_{2}$ partial pressure was of the same order as it was at the inlet of the cell, suggesting that only a small fraction of $\mathrm{O}_{2}$ has reacted in the test solution. This result illustrates that, during the first hours of the test in both solutions, the major reaction is the corrosion of iron, which produces alkalinity and dissolved iron and consequently increases the $\mathrm{pH}$. Once iron sulfide saturation is reached, the $\mathrm{pH}$ stops increasing. Particularly, in the test solution exposed to $\mathrm{O}_{2}$ pollution, there are additional reactions between oxygen and $\mathrm{H}_{2} \mathrm{~S}$-producing $\mathrm{S}-\mathrm{O}$ species that acidify the medium. This is in agreement with separate reports from Song, et al., and Crolet, et al., who proposed the following reactions: ${ }^{3-4}$

$$
\begin{aligned}
& 2 \mathrm{H}_{2} \mathrm{~S}+\mathrm{O}_{2} \rightarrow 2 \mathrm{~S}+2 \mathrm{H}_{2} \mathrm{O} \\
& 2 \mathrm{H}_{2} \mathrm{~S}+2 \mathrm{O}_{2} \rightarrow \mathrm{S}_{2} \mathrm{O}_{3}{ }^{2-}+\mathrm{H}_{2} \mathrm{O}+2 \mathrm{H}^{+} \\
& 4 \mathrm{H}_{2} \mathrm{~S}+9 / 2 \mathrm{O}_{2} \rightarrow \mathrm{S}_{4} \mathrm{O}_{6}{ }^{2-}+3 \mathrm{H}_{2} \mathrm{O}+2 \mathrm{H}^{+}
\end{aligned}
$$

Over a long time period, this cumulative acidification can have a considerable effect on the $\mathrm{pH}$ of the solution.

In addition to in situ $\mathrm{pH}$ measurements, periodic sampling of the test solutions was performed for chemical analysis by IC. The main results are plotted in Figure 3. Before analysis, residual dissolved $\mathrm{H}_{2} \mathrm{~S}$ was eliminated by argon stripping in the water aliquot. Eliminating dissolved $\mathrm{H}_{2} \mathrm{~S}$ before the IC analysis was required because $\mathrm{H}_{2} \mathrm{~S}$ was found to be highly reactive with the column and might lead to fast deterioration of the equipment. The main dissolved sulfur compound detected was sulfate. Sulfite and thiosulfate were also found at lower concentrations.

In the test solution with oxygen, the sulfate concentration increases gradually and reaches $100 \mathrm{mg} / \mathrm{L}$ at the end of the test after 4-weeks exposure. Sulfites and thiosulfates are also detected at trace levels. A yellowish elemental sulfur deposit was also observed in the corresponding test cell. These results are in good agreement with Reactions (2) through (4).

According to these reactions, thiosulfate is an expected reaction product, although it is known to be unstable and can oxidize to sulfate and elemental sulfur in an oxygen-containing environment. ICPES results showed that $\mathrm{H}_{2} \mathrm{~S}$ solution treated with oxygen consisted of $45 \mathrm{ppm}$ of total sulfur. Hence, approximately $70 \%$ of the sulfur compounds detected by IC comprise dissolved sulfur. On the contrary, tests conducted without added oxygen did not show any elemental sulfur precipitation and no significant increase of sulfate, sulfite, or thiosulfate content.

At the end of the test, the dissolved iron content for the oxygen-free test is about $0.35 \mathrm{mg} / \mathrm{L}$, and about $38 \mathrm{mg} / \mathrm{L}$ for the test in the presence of oxygen. This higher value of the dissolved iron content in the presence of oxygen is probably the result of the acidification of the solution, which increases the solubility of iron. At the same time, bulk precipitation consisting mainly of elemental sulfur was also observed. 


\section{Impact of Oxygen on Corrosion}

The results showing the effect of oxygen on weight-loss corrosion rate are presented in Table 2. Four series of tests were performed in parallel, with and without oxygen.

For the four replicate tests, the average corrosion rate in $\mathrm{H}_{2} \mathrm{~S}$-containing test solutions without $\mathrm{O}_{2}$ pollution is $489 \mu \mathrm{m} / \mathrm{y} \pm$ $68 \mu \mathrm{m} / \mathrm{y}$. Conversely, oxygen pollution results in a strong increase in the corrosion rate, which is $976 \mu \mathrm{m} / \mathrm{y} \pm 248 \mu \mathrm{m} / \mathrm{y}$. This increase in corrosion rate can be associated with the continuous decrease of $\mathrm{pH}$ due to $\mathrm{O}_{2}-\mathrm{H}_{2} \mathrm{~S}$ reactions, which is expected to enhance the cathodic reaction. It is also possible that thiosulfate, or other unstable S-O species that may have formed, contribute directly to the cathodic current density and increase the corrosion rate. The higher dispersion of corrosion rates for the tests with $\mathrm{O}_{2}$ might result from a less homogeneous solution, especially with regards to $\mathrm{O}_{2}-\mathrm{H}_{2} \mathrm{~S}$ reaction products. One observation worth noting was that weight-loss coupons placed closer to the gas frit exhibited more severe corrosion. Unfortunately, magnetic bar stirring was not possible during our tests, because it resulted in significant disturbance of permeation measurements. Taking into account the test durations and the ratio between the surface of metal and the volume of test solution, these corrosion rates correspond to the release of $1.3 \mathrm{~g}$ (without $\mathrm{O}_{2}$ ) or $2.5 \mathrm{~g}\left(\right.$ with $\mathrm{O}_{2}$ ) of iron per liter of test solution. Comparison with dissolved iron measured at the end of the tests $(0.35 \mathrm{mg} / \mathrm{L}$ and $38 \mathrm{mg} / \mathrm{L}$, respectively) confirms massive precipitation of FeS in solution.

In addition to weight-loss coupons, corrosion rates were also evaluated through electrochemical measurements at the entry face of the permeation membrane. Time evolution of corrosion potentials $\left(\mathrm{E}_{\mathrm{oc}}\right)$ is plotted in Figure 4. Without $\mathrm{O}_{2}, \mathrm{E}_{\mathrm{oc}}$ remains stable during the entire test period, at $-0.69 \mathrm{~V}_{\mathrm{Ag} / \mathrm{AgCl}} \pm 0.01 \mathrm{~V}_{\mathrm{Ag} / \mathrm{AgCl}}$. On the contrary, $\mathrm{O}_{2}$ pollution induces a slight, but continuous increase of $E_{o c}$. The amplitude of $E_{o c}$ increase at the end of the test $(+30 \mathrm{mV})$ is well correlated with the $\mathrm{pH}$ evolution (+1 pH unit), considering Tafel slopes of $40 \mathrm{mV}$ and $120 \mathrm{mV}$ for the anodic and cathodic reactions, respectively.

Typical impedance diagrams obtained after various exposure times with or without $\mathrm{O}_{2}$ pollution are presented in Figure 5.

EIS analysis required the development of a specific model, with all details provided in a previous work. ${ }^{16}$ This model takes into account the build-up of a highly porous and conductive iron sulfide layer, represented by $Z_{\text {film }}$. As a result of a distribution of pore sizes, the impedance of this film presents a dual behavior with two parallel contributions: (i) corresponding to a plane electrode (Equation [5]) and (ii) corresponding to a porous electrode (Equation [6]). In these expressions, $Z_{\text {eq }}$ defines the interfacial impedance at the surface of the conductive film inside the pores, and $n, r$, and 1 are the number of pores, their radius, and their length, respectively. The square root term of the porous electrode contribution explains the $45^{\circ}$ inclination of the impedance at long exposure times observed in pure $\mathrm{H}_{2} \mathrm{~S}$ without $\mathrm{O}_{2}$ pollution. The resulting equivalent circuit is given in Figure 6, where $Z_{\text {film }}$ corresponds to the contribution of the corrosion product scale given by Equation (7), $R_{t}$ is the charge transfer resistance associated with the double layer capacitance constant phase element (CPE), $C P E_{\mathrm{dl}}$, and $\mathrm{R}_{\mathrm{a}}$ and $\mathrm{CPE}_{\mathrm{a}}$ are associated with the adsorption-desorption step of anodic dissolution. CPEs were used instead of pure capacitance as a result of time-constant distribution associated with surface heterogeneities. At very short immersion times, when the corrosion product scale is very thin, the contribution of $Z_{\text {film }}$ is negligible, and the equivalent circuit is then similar to that used by Ma, et al., in $\mathrm{H}_{2} \mathrm{~S}$ solutions at lower $\mathrm{pH} .{ }^{17-18}$

$$
\begin{aligned}
& Z_{\text {film,plane }}=Z_{\text {pore }} / n=Z_{\text {eq }} / 2 n \pi r l \\
& Z_{\text {film,porous }}=\sqrt{\rho Z_{\text {eq }}} / \sqrt{2} n \pi r^{3 / 2} \\
& Z_{\text {film }}{ }^{-1}=Z_{\text {film,plane }}{ }^{-1}+Z_{\text {film,porous }}{ }^{-1}
\end{aligned}
$$


All EIS spectra were analyzed with this equivalent circuit. The main difference between both cases becomes apparent at long exposure times. For the tests in pure $\mathrm{H}_{2} \mathrm{~S}$ solution (Figure 5[a]), impedance diagrams tend to incline at $45^{\circ}$, but the second capacitive loop associated with the adsorption step maintains a high diameter. On the contrary, in presence of $\mathrm{O}_{2}$, the resistance of the first capacitive loop (charge transfer) decreases with time, together with a much stronger decrease of the low frequency contribution associated with the adsorption step. The values of the equivalent circuit components corresponding to the charge transfer loop for EIS diagrams of Figure 5 are given in Table 3.

From EIS analysis, corrosion current densities $\left(\mathrm{J}_{\text {corr }}\right)$ were calculated from $\mathrm{R}_{\mathrm{t}}$ using the Stern and Geary relationship. As shown in a previous paper, EIS diagrams are dominated by the impedance of anodic reactions. ${ }^{16}$ As a consequence, a modified version of the Stern and Geary relationship was used, considering only the anodic Tafel coefficient $\left(b_{a}\right)$. A value of $40 \mathrm{mV}$ was used, as usually observed in $\mathrm{H}_{2} \mathrm{~S}$ environments: ${ }^{19}$

$$
\mathrm{J}_{\text {corr }}=\mathrm{b}_{\mathrm{a}} / 2.3 \mathrm{R}_{\mathrm{t}}
$$

The evolution of corrosion current densities with exposure time are compared in Figure 7 for the experiments conducted with and without $\mathrm{O}_{2}$ pollution. As already shown by weight-loss test results, the acceleration of corrosion rates by $\mathrm{O}_{2}$ pollution is confirmed. Through EIS monitoring, it is also shown that the acceleration is not immediate. During the first days, corrosion rates are similar in both experiments, starting close to $0.8 \mathrm{~mm} / \mathrm{y}$, and quickly decreasing to $0.5 \mathrm{~mm} / \mathrm{y}$ to $0.6 \mathrm{~mm} / \mathrm{y}$ after $1 \mathrm{~d}$ or $2 \mathrm{~d}$. However, although the iron corrosion rate remained stable for the remaining 3 weeks in the reference situation, it started to increase after approximately $300 \mathrm{~h}$ in presence of $\mathrm{O}_{2}$ pollution. At the end of the test, the corrosion rate was close to $1.8 \mathrm{~mm} / \mathrm{y}$. This increase is well correlated with the $\mathrm{pH}$ evolution shown in Figure 2. For both test solutions, an excellent agreement was found between the average corrosion rate calculated from electrochemical measurements $\left(530 \mu \mathrm{m} / \mathrm{y}\right.$ and $905 \mu \mathrm{m} / \mathrm{y}$ without or with $\mathrm{O}_{2}$ pollution, respectively) and weight-loss measurements (490 $\mu \mathrm{m} / \mathrm{y}$ and $976 \mu \mathrm{m} / \mathrm{y}$ without or with $\mathrm{O}_{2}$ pollution, respectively).

Surface analysis of the coupons was also performed. Results of XRD analysis showed that mackinawite (FeS) was the dominant phase, with some traces of greigite $\left(\mathrm{Fe}_{3} \mathrm{~S}_{4}\right)$. No iron oxides or hydroxides were detected for the tests conducted with $\mathrm{O}_{2}$ pollution. Although our XRD methodology did not identify any notable differences between scale compositions formed at the iron surface in either solution type, the same cannot be said for SEM (Figure 8). For oxygen-free tests, a rather homogeneous surface is observed, mainly composed of iron and sulfur as shown by electron-dispersive spectroscopy (EDS) mapping. On the other hand, for iron samples exposed to aqueous oxygen, EDS mapping shows differences in the deposits. Surfaces appear inhomogeneous, and cracked, with some zones confirmed to be rich in oxygen and others rich in sulfur. In addition, in the tests performed in the presence of oxygen, extensive precipitation was also observed on the walls of the test cells. XRD analysis was performed on these deposits, confirmed to consist mainly of elemental sulfur and marcasite. Although not detected at the surfaces of the corroded iron coupons, elemental sulfur might have been deposited and contributed to an increase of corrosion rate. From our point of view, the increase in the quantity of bulk precipitation in the presence of $\mathrm{O}_{2}$ was unexpected. Indeed, the lowering of $\mathrm{pH}$ should favor acid dissolution of iron sulfide minerals. However, it appears that $\mathrm{O}_{2}$ ingress compensates this phenomenon by promoting other forms of precipitates. We accept that an analysis of surface and bulk precipitates was not fully addressed in the current work, in order to elucidate these antagonistic effects.

\section{Impact of $\mathrm{O}_{2}$ on Hydrogen Permeation}

In order to verify the reproducibility of electrochemical permeation measurements, five series of tests were performed in the model solution $\left(35 \mathrm{~g} / \mathrm{L} \mathrm{NaCl}\right.$ solution) under $0.1 \mathrm{MPa}_{2} \mathrm{~S}$. The results obtained are shown in Figure 9 . It is observed on permeation transients that after $40 \mathrm{~h}$ of test, permeation current densities of between $41 \mu \mathrm{A} / \mathrm{cm}^{2}$ and $48 \mu \mathrm{A} / \mathrm{cm}^{2}$ are obtained, i.e., a variation of less than $10 \%$ around the average. In presence of oxygen, the interval between the highest and lowest values of five replicates is slightly higher, and it reaches approximately $20 \%$ after $600 \mathrm{~h}$. 
The effects of oxygen on permeation through a pure iron membrane in $\mathrm{NaCl}$-saturated solution with $0.1 \mathrm{MPa}_{2} \mathrm{~S}$ are illustrated in Figure 10. It must be noted that impedance measurements of the entry face were performed periodically during all of the tests, leading to small fluctuations of the permeation current. This explains the visual impression of noise on these permeation transients. No particular effect of oxygen is observed on the permeation current during the first $100 \mathrm{~h}$ of the test. However, after $200 \mathrm{~h}$, a monotonic decrease in the hydrogen permeation current is measured in the presence of $\mathrm{O}_{2}$. After $620 \mathrm{~h}$ of tests, the permeation current density was approximately $19 \mu \mathrm{A} / \mathrm{cm}^{2}$ and $39 \mu \mathrm{A} / \mathrm{cm}^{2}$ in the solution with and without oxygen, respectively. This trend is reproducible for the four sets of tests that have been done under these conditions. Such a decrease in the permeation current is rather unexpected, considering that the $\mathrm{pH}$ decreases with time down to 3.2 (with oxygen), while it stayed close to 4.4 (without oxygen). Indeed, increasing the acidity should normally have the opposite effect, with an increase of permeation rate. ${ }^{7,20}$

Comparing corrosion and permeation rates also gives an interesting perspective. The impedance measurements permit the evaluation of corrosion current densities of the iron membrane surface as a function of time over the test period (Figure 7), whereas the hydrogen permeation rates provide an indication of the hydrogen flux through the same membrane. This comparison is presented in Figure 11. For both tests, the permeation efficiency $\left(\mathrm{E}_{\text {perm }}\right)$ was also plotted. This parameter is calculated from the ratio between the permeation current density and the corrosion current density, expressed in percentage. For the test conducted without $\mathrm{O}_{2}$, there is a remarkable equality between the corrosion current density and the hydrogen permeation current density (Figure 11). This result is a clear evidence that the cathodic reaction involved in pure $\mathrm{H}_{2} \mathrm{~S}$ systems consists only of proton reduction (via dissociated $\mathrm{H}^{+}$and direct $\mathrm{H}_{2} \mathrm{~S}$ reduction), and also that the permeation efficiency is $100 \%$, suggesting that $100 \%$ of hydrogen produced by the cathodic reaction enters the iron membrane. Such behavior is observed in particular hydrogen permeation systems, provided that there is no impediment to hydrogen entry, that no hydrogen diffusion limitation in the metal takes place (i.e., thin membrane, low trapping), and that the hydrogen extraction is efficient. ${ }^{71}$ On the contrary, the tests with $\mathrm{O}_{2}$ pollution depict a clear deviation between corrosion and permeation rates after a few days exposure (Figure 12). Although the permeation efficiency was close to $100 \%$ at the beginning of the test, it decreases to $12 \%$ after $26 \mathrm{~d}$.

At this point in the discussion, we identify three hypotheses to explain the decrease of permeation efficiency in the $\mathrm{O}_{2}$ polluted system. (1) Considering the role of the corrosion products formed in the presence of dissolved $\mathrm{H}_{2} \mathrm{~S}-\mathrm{O}_{2}$, the higher quantity of surface and bulk precipitates were expected to provide a blocking effect, reducing electrochemical reactions at the metal surface. However, such a hypothesis is contradicted by the fact that $\mathrm{O}_{2}$ pollution also resulted in doubling the corrosion rate. Because $\mathrm{H}$-entry into metals in $\mathrm{H}_{2} \mathrm{~S}$ systems is understood to be a result of corrosion, an electrode blocking effect would lower both the corrosion rate and the permeation current. However, this is not observed. (2) The second hypothesis considers that dissolved $\mathrm{O}_{2}$, or more likely the reaction products of dissolved $\mathrm{O}_{2}$ and $\mathrm{H}_{2} \mathrm{~S}$, have a significant contribution to the cathodic reaction electrochemistry. We reiterate that thiosulfates have been identified as a candidate reaction product, possibly leading to the following electrochemical contribution: ${ }^{21}$

$$
\mathrm{S}_{2} \mathrm{O}_{3}{ }^{2-}+6 \mathrm{H}^{+}+4 \mathrm{e}^{-} \rightarrow 2 \mathrm{~S}+3 \mathrm{H}_{2} \mathrm{O}
$$

The direct reduction of oxygen can also be considered. The common feature of these reactions is that they do not produce "atomic hydrogen," i.e., they do not contribute to hydrogen entry in the steel, although promoting an increase in the corrosion rate.

(3) The third hypothesis to explain the decrease of hydrogen permeation current density over time is to consider a decrease of hydrogen entry promotion at the metal surface, i.e., a modification of the catalytic activity. Because hydrogen entry is suggested to be promoted by the action of specific adsorbates $\left(\mathrm{H}_{2} \mathrm{~S}, \mathrm{HS}^{-}\right)$, which play the role of intermediate reactants during proton reduction, ${ }^{6,8}$ those present in an $\mathrm{O}_{2}$-polluted solution may be less efficient than those observed in pure $\mathrm{H}_{2} \mathrm{~S}$ media. A theoretical analysis proposed by Marcus and Protopopoff compared the adsorption of oxygen or sulfur atoms on iron, in various environments containing $\mathrm{H}_{2} \mathrm{~S}$ and thiosulfates. ${ }^{22}$ According to these authors, the presence of thiosulfate could modify the ratio between $\mathrm{O}_{\text {ads }}$ and $\mathrm{S}_{\mathrm{ads}}$, with potential consequences on the anodic reaction and on the enhancement of $\mathrm{H}$ entry into the metal. 
In order to discriminate between bulk (Hypothesis 2) and surface (Hypothesis 3) reactions to explain the decrease of hydrogen permeation, two additional experiments were performed. The first one consisted of preparing a test solution by exposing iron to an $\mathrm{O}_{2}-\mathrm{H}_{2} \mathrm{~S}$ solution for 3 weeks. This "aged" test solution, already polluted by $\mathrm{O}_{2}-\mathrm{H}_{2} \mathrm{~S}$ reaction products and with a $\mathrm{pH}$ of 3.6, was then used for a permeation test on a fresh iron membrane. The resulting hydrogen permeation transient is presented in Figure 13, where it is compared with a transient obtained with a fresh solution. Both permeation transients are within the dispersion band of $\pm 10 \%$, suggesting that the decrease of permeation efficiency is perhaps not linked to bulk solution composition.

Finally, in order to differentiate between bulk solution chemistry (Hypothesis 2) and surface reaction chemistry (Hypothesis 3) another type of test was performed. This experiment commenced like all previous tests with $\mathrm{O}_{2}$ pollution, with hydrogen permeation being measured for $15 \mathrm{~d}$ (Figure 14). After this period, the permeation current density had decreased down to $35 \mu \mathrm{A} / \mathrm{cm}^{2}$, and test solution $\mathrm{pH}$ was 3.5. Subsequently, taking all necessary precautions to avoid accidental oxygen entry, the test solution was drained; it was immediately replaced with a fresh solution saturated with $\mathrm{H}_{2} \mathrm{~S}$ (containing oxygen) at a $\mathrm{pH}$ of 4 . As Figure 14 confirms, the permeation current density remained unchanged after replacement of the test solution, suggesting that the contributions of the bulk solution chemistry reaction products are not highly relevant toward a diminution of the rate of hydrogen uptake. By a process of elimination, this result strongly indicates that the decrease of permeation efficiency is controlled by the changes to the nature and catalytic activity at the surface of the iron electrode, rather than by impurities in the test solution.

\section{CONCLUSIONS AND FUTURE WORK}

The effect of traces of oxygen on the corrosion of, and hydrogen permeation across, pure iron was studied in a $35 \mathrm{~g} / \mathrm{L}$ $\mathrm{NaCl}$ test solution saturated with $0.1 \mathrm{MPa}_{2} \mathrm{~S}$, as a function of time over 3 to 4 weeks. $\mathrm{O}_{2}$ pollution was introduced in a continuous manner in the test gas, at a partial pressure of $1.3 \mathrm{kPa}$ corresponding to 500 mass ppb dissolved $\mathrm{O}_{2}$ at equilibrium. The following conclusions were drawn from this study:

- $\mathrm{O}_{2}$ pollution in an $\mathrm{H}_{2} \mathrm{~S}$-saturated solution has strong influence on, and modifies, the test solution chemistry. Although the main $\mathrm{O}_{2}-\mathrm{H}_{2} \mathrm{~S}$ soluble reaction product is sulfate, the presence of the unstable intermediate species sulfite and thiosulfate are also detected; these are suspected of reacting with the metal before the more stable sulfate form is reached. Indeed, in the presence of $\mathrm{O}_{2}$, elemental sulfur precipitates are also detected. As expected, such solution chemistry reaction pathways lead to a strong acidification of the test medium, dropping by $1 \mathrm{pH}$ unit over a period of 1 month.

* Corrosion is strongly accelerated in the presence of $\mathrm{O}_{2}$, on average by a factor of about 2, during exposures lasting 3 to 4 weeks. EIS evaluations at various exposure times show that the corrosion rate acceleration is not immediate and appears to follow the $\mathrm{pH}$ drift resulting from $\mathrm{O}_{2}$ pollution. After 1 month exposure, the instantaneous corrosion rate was close to $0.5 \mathrm{~mm} / \mathrm{y}$ in the reference system ( $\mathrm{pH} 4.4$ ), while it was in the order of $1.8 \mathrm{~mm} / \mathrm{y}$ in presence of $\mathrm{O}_{2}$, with a $\mathrm{pH}$ close to 3.2. Differences are also observed in the morphology and homogeneity of corrosion deposits, with more oxides and elemental sulfur present in the case of $\mathrm{O}_{2}$-polluted systems. In addition, in both cases (with and without $\mathrm{O}_{2}$ ), XRD analyses show that crystalline mackinawite is the majority compound. Test solution acidification is thought to be the major reason for enhancing the corrosion rate.

* As EIS measurements were being performed on the entry face of the thin membrane, hydrogen permeation was measured on the opposite face. In the reference situation without $\mathrm{O}_{2}$ pollution, corrosion current densities and hydrogen permeation current present similar values. This permeation efficiency of $100 \%$ was expected, because the system presents an efficient hydrogen entry promoter (i.e., a high $\mathrm{H}_{2} \mathrm{~S}$ concentration) and a thin membrane. Unexpectedly, hydrogen permeation does not follow the same trends in the presence of $\mathrm{O}_{2}$ pollution. Whereas corrosion rate increased as a result of test solution acidification, permeation efficiency continuously decreased. Through additional tests, we show that this decrease was mainly associated with changes to the surface reaction rates of hydrogen uptake. 
In the next parts of this series of papers, similar experiments will be performed at various $\mathrm{H}_{2} \mathrm{~S}$ concentrations. In addition, in order to obtain a more direct comparison of NACE standard test conditions (e.g., as per NACE TM0284 or NACE TM0177) some tests will be conducted in buffered solutions and with steel grades used for oil and gas production.

\section{ACKNOWLEDGMENTS}

The authors express their gratitude to Alexandre Bonneau for his active participation in the implementation of the experimental setup and Remy Mingant, for EIS analysis. The contribution of IFPEN analysis department in the surface characterization and solution analysis is also greatly acknowledged. Special thanks are also addressed to G. Joshi for the final proofreading.

\section{REFERENCES}

1. NACE TM0177-2016, "Laboratory Testing of Metals for Resistance to Sulfide Stress Cracking and Stress Corrosion Cracking in $\mathrm{H}_{2} \mathrm{~S}$ Environments" (Houston, TX: NACE International, 2016).

2. NACE TM0284-2016, "Evaluation of Pipeline and Pressure Vessel Steels for Resistance to Hydrogen-Induced Cracking" (Houston, TX: NACE International, 2016).

3. Y. Song, A. Palencsar, G. Svenningsen, J. Kvarekval, T. Hemmingsen, Corrosion 68, 7 (2012): p. 662-671.

4. J.L. Crolet, M. Pourbaix, A. Pourbaix, "The Role of Trace Amounts of Oxygen on the Corrosivity of $\mathrm{H}_{2} \mathrm{~S}$ Media," CORROSION/91, held 10-15, March, paper no. 22 (Houston, TX: NACE, 1991).

5. H.S. Kuo, H. Chang, W.T. Tsai, Corros. Sci. 41, 4 (1999): p. 669-684.

6. A. Kawashima, K. Hashimoto, S. Shimodaira, Corrosion 32, 8 (1976): p. 321-331.

7. T. Zakroczymski, Z. Szklarska-Smiatowska, M. Smiatowski, Werkstoffe und Korrosion 27 (1976).

8. B. Le Boucher, Revue de l'Institut Francais du Petrole 23, 4 (1963): p. 1-66.

9. M. Kappes, G.S. Frankel, N. Sridhar, R.M. Carranza, J. Electrochem. Soc. 159, 4 (2012): p. C195.

10. M.H. Abd Elhamid, B.G. Ateya, K.G. Weil, H.W. Pickering, Corrosion 57, 5 (2001): p. 428-432.

11. R. Battino, T.R. Rettich, T. Tominaga, J. Phys. Chem. Ref. Data 12, 2 (1983): p. 163-178.

12. J.J. Carroll, A.E. Mather, Geochimica et Cosmochimica Acta 53, 6 (1989): p. 1163-1170.

13. M.A.V. Devanathan, Z. Stachurski, J. Electrochem. Soc. 111, 5 (1964): p. 619-623.

14. P. Manolatos, M. Jerome, Electrochim. Acta 41, 3 (1996): p. 359-365.

15. S. Wach, A.P. Miodownik, J. Mackowiak, Corros. Sci. 6 (1966).

16. M.D. Deffo-Ayagou, T.T. Mai Tran, B. Tribollet, J. Kittel, E. Sutter, N. Ferrando, C. Mendibide, C. Duret-Thual, Electrochim. Acta 282 (2018): p. 775-783.

17. H.Y. Ma, X.L. Cheng, S.H. Chen, G.Q. Li, X. Chen, S.B. Lei, H.Q. Yang, Corrosion 54, 8 (1998): p. 634-640.

18. H.Y. Ma, X.L. Cheng, G.Q. Li, S.H. Chen, Z.L. Quan, S.Y. Zhao, L. Niu, Corros. Sci. 42, 10 (2000): p. 1669-1683.

19. Y. Zheng, "Electrochemical Mechanism and Model of $\mathrm{H}_{2} \mathrm{~S}$ Corrosion of Carbon Steel," Ph.D. dissertation, The Russ College of Engineering and Technology of Ohio University, 2015.

20. J. Kittel, F. Ropital, J. Pellier, Corrosion 64, 10 (2008): p. 788-799.

21. S. Tsujikawa, A. Miyasaka, M. Ueda, S. Ando, T. Shibata, T. Haruna, M. Katahira, Y. Yamane, T. Aoki, T. Yamada, Corrosion 49, 5 (1993): p. 409-419.

22. P. Marcus, E. Protopopoff, Corros. Sci. 39, 9 (1997): p. 1741-1752.

\section{TABLE CAPTIONS}

TABLE 1. Chemical Composition of Test Material (ppmw)

\begin{tabular}{|l|c|c|c|c|c|c|c|c|c|c|}
\hline $\mathrm{Al}$ & $\mathrm{Cr}$ & $\mathrm{Cu}$ & $\mathrm{Mn}$ & $\mathrm{Ni}$ & $\mathrm{Si}$ & $\mathrm{Ti}$ & $\mathrm{C}$ & $\mathrm{P}$ & $\mathrm{S}$ & $\mathrm{Fe}$ \\
\hline 107 & 133 & 55 & 240 & 159 & 100 & 5 & 18 & 60 & 48 & $>99500$ \\
\hline
\end{tabular}

TABLE 2. Corrosion rates $(\mu \mathrm{m} / \mathrm{y})$ of Iron Coupons Exposed to Test Solution Composed of $35 \mathrm{~g} / \mathrm{L} \mathrm{NaCl}$ with $0.1 \mathrm{MPa}$ $\mathrm{H}_{2} \mathrm{~S}$, with and Without $\mathrm{O}_{2}$ Pollution

\begin{tabular}{|l|c|c|c|}
\hline & $\mathrm{H}_{2} \mathrm{~S}(\mathrm{a})$ & $\mathrm{H}_{2} \mathrm{~S}+\mathrm{O}_{2}(\mathrm{~b})$ & $(\mathrm{b}-\mathrm{a}) / \mathrm{a}(\%)$ \\
\hline Test 1 & 480 & 1,025 & 114
\end{tabular}


Test 2

Test 3

Test 4

Average

$$
\begin{aligned}
& 411 \\
& 576 \\
& 487
\end{aligned}
$$

$489 \pm 68$

$$
687
$$

1,283

907

$976 \pm 248$
67

123

86

$97 \pm 25$

TABLE 3. Values of EC Components Related to the Charge Transfer Loop Obtained from the Analysis of Electrochemical Impedance Spectroscopy Data

\begin{tabular}{l|ccccccc|}
\hline & \multicolumn{3}{|c|}{$\mathrm{H}_{2} \mathrm{~S}$} & \multicolumn{3}{c|}{$\mathrm{H}_{2} \mathrm{~S}+\mathrm{O}_{2}$} \\
& $2 \mathrm{~h}$ & $47 \mathrm{~h}$ & $572 \mathrm{~h}$ & $2 \mathrm{~h}$ & $47 \mathrm{~h}$ & $572 \mathrm{~h}$ \\
$\mathrm{R}_{\mathrm{e}}\left(\Omega \cdot \mathrm{cm}^{2}\right)$ & 143 & 140 & 136 & 136 & 135 & 132 \\
$\mathrm{R}_{\mathrm{t}}\left(\Omega \cdot \mathrm{cm}^{2}\right)$ & 276 & 381 & 458 & 254 & 336 & 168 \\
$\mathrm{Q}_{\mathrm{dl}}(\mathrm{mF} \cdot \mathrm{s}$ & $\left.(\alpha-1) / \mathrm{cm}^{2}\right)$ & 3 & 13 & 44 & 3 & 12 & 14 \\
$\alpha$ & 0.89 & 0.90 & 0.88 & 0.85 & 0.86 & 0.78 \\
\hline
\end{tabular}

\section{FIGURE CAPTIONS}
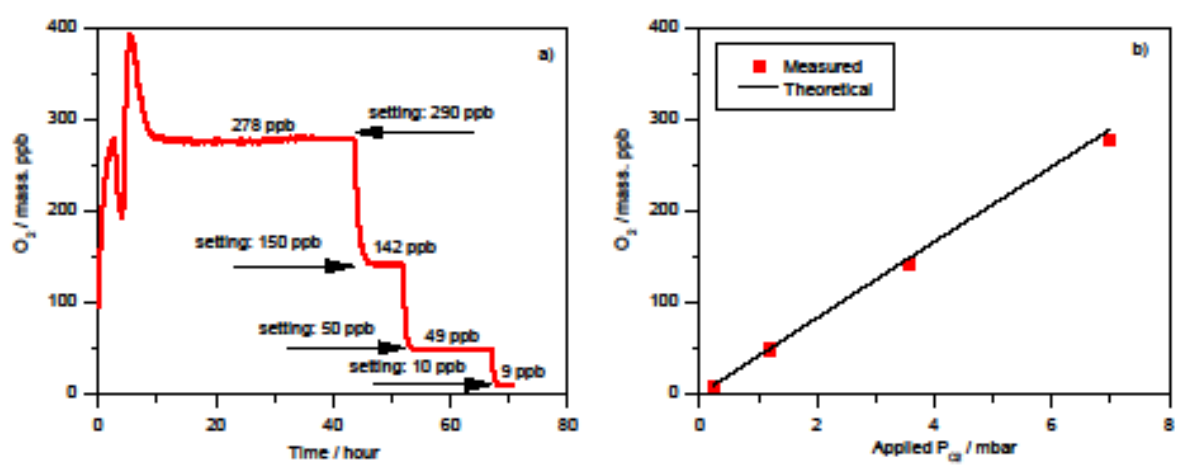

\section{Figure 1}

FIGURE 1. Verification of $\mathrm{O}_{2}$ control at various levels in the test medium (a) and comparison with theoretical values (b).

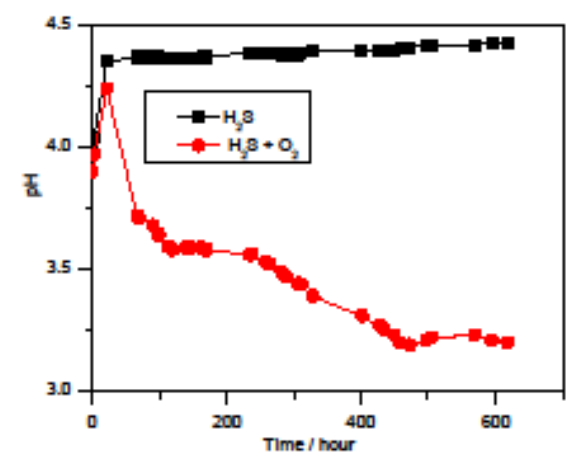

Figure 2

FIGURE 2. $\mathrm{pH}$ evolution in the corrosion test solution composed of $35 \mathrm{~g} / \mathrm{L} \mathrm{NaCl}$ with $0.1 \mathrm{MPa}_{2} \mathrm{~S}$, including the impact of a continuous contamination of $500 \mathrm{ppb} \mathrm{O}_{2}$. 


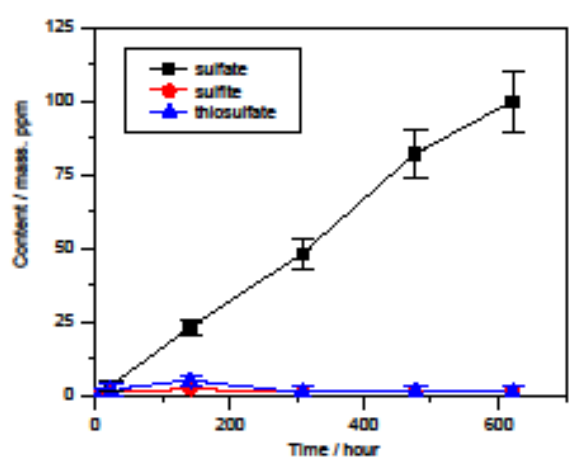

\section{Figure 3}

FIGURE 3. Chemical analysis by ionic chromatography of S-O species in test solutions composed of $35 \mathrm{~g} / \mathrm{L} \mathrm{NaCl}$ with $0.1 \mathrm{MPa} \mathrm{H}_{2} \mathrm{~S}$, without (a) and with (b) continuous $\mathrm{O}_{2}$ contamination at $500 \mathrm{ppbw}$

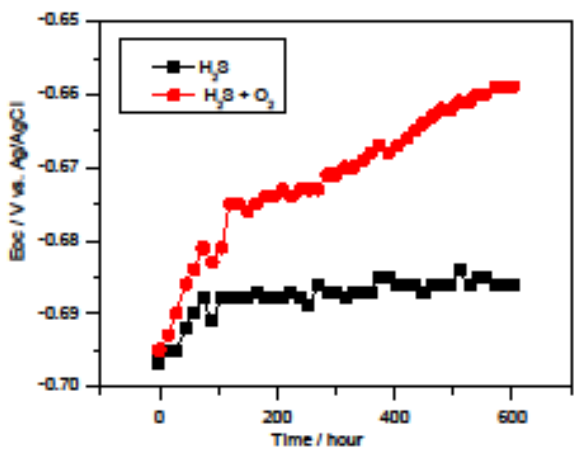

\section{Figure 4}

FIGURE 4. Time evolution of corrosion potentials of pure iron membranes exposed to $35 \mathrm{~g} / \mathrm{L} \mathrm{NaCl}$ solution saturated with $0.1 \mathrm{MPa} \mathrm{H}_{2} \mathrm{~S}$, with and without $\mathrm{O}_{2}$ pollution.
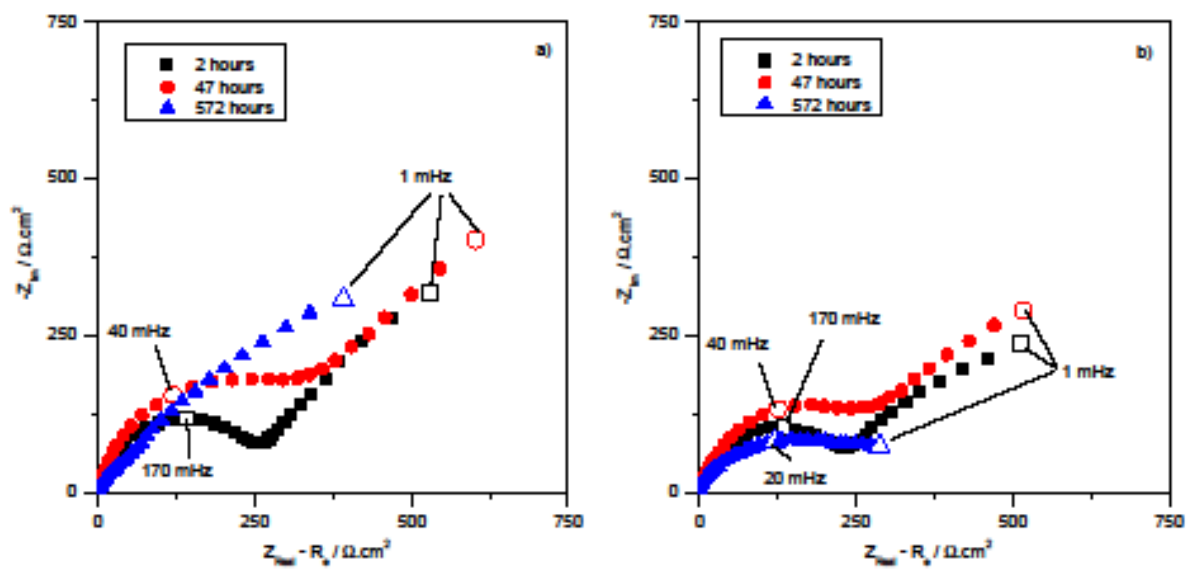

Figure 5 
FIGURE 5. Typical impedance spectra of pure iron in $\mathrm{NaCl} 35 \mathrm{~g} / \mathrm{L}$ solution saturated with $0.1 \mathrm{MPa}_{2} \mathrm{~S}$ at various exposure times, without (a) and with (b) $\mathrm{O}_{2}$ pollution.

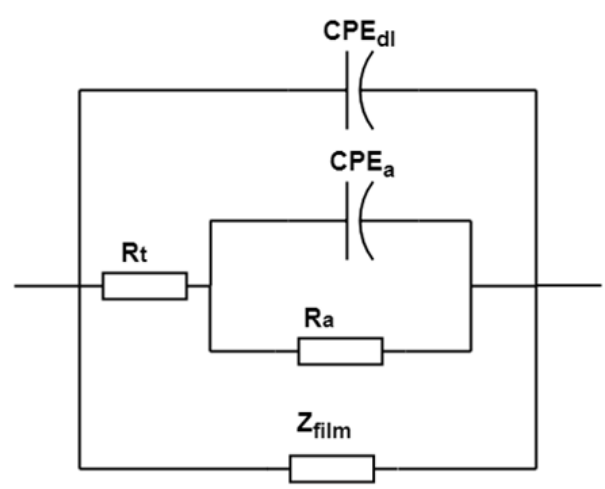

Figure 6

FIGURE 6. Equivalent circuit for the corrosion of pure iron in $\mathrm{H}_{2} \mathrm{~S}$-containing environment with the formation of a conductive and porous FeS layer. ${ }^{16}$

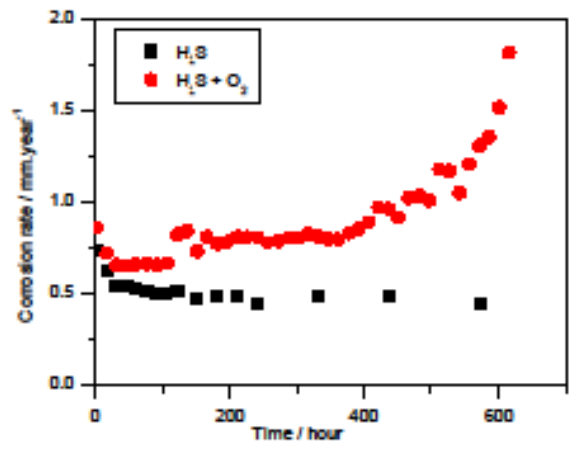

\section{Figure 7}

FIGURE 7. Evolution of corrosion current densities obtained from electrochemical impedance spectroscopy measurements, with and without $\mathrm{O}_{2}$ pollution. 

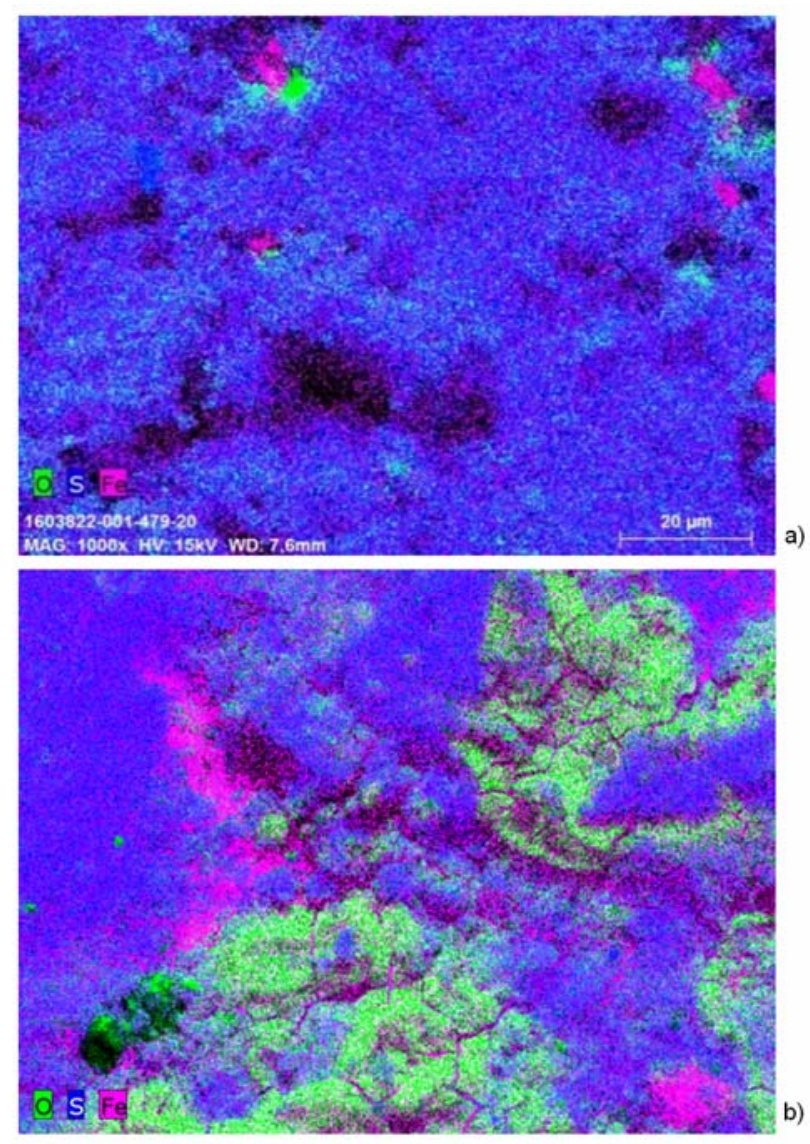

FIGURE 8. Electron-dispersive spectroscopy mapping for corrosion products at the metal surface after tests (a) without oxygen (b) with oxygen (same magnification for both pictures).

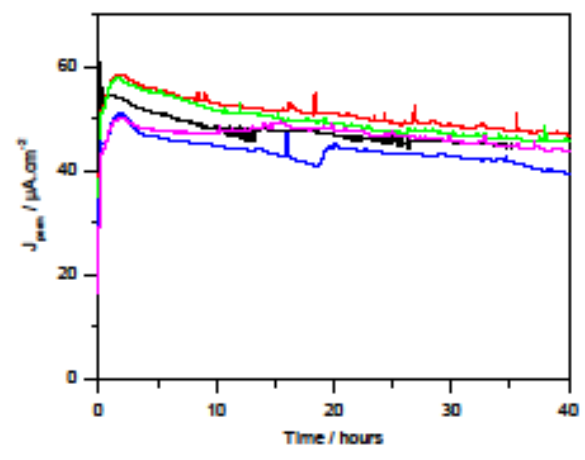

\section{Figure 9}

FIGURE 9. Reproducibility of permeation measurements in $35 \mathrm{~g} / \mathrm{L} \mathrm{NaCl}$ solution under $0.1 \mathrm{MPa}_{2} \mathrm{~S}$. 


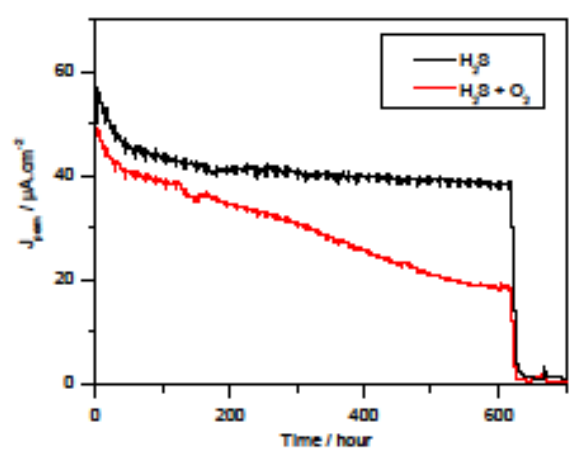

Figure 10

FIGURE 10. Permeation curves in $35 \mathrm{~g} / \mathrm{L} \mathrm{NaCl}$ under $0.1 \mathrm{MPa}_{2} \mathrm{~S}$, with and without oxygen.

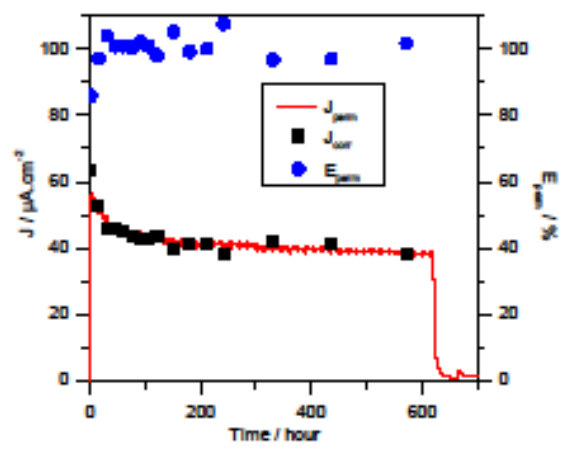

Figure 11

FIGURE 11. Comparisons between $\mathrm{J}_{\text {corr }}$ and $\mathrm{J}_{\text {perm, }}$ and evolution of the permeation efficiency, as a function of time for the test without $\mathrm{O}_{2}$ pollution.

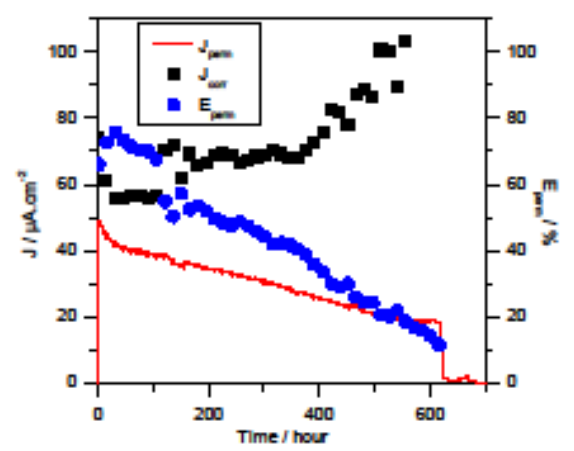

Figure 12

FIGURE 12. Comparisons between $\mathrm{J}_{\text {corr }}$ and $\mathrm{J}_{\text {perm }}$, and evolution of the permeation efficiency, as a function of time for the test with $\mathrm{O}_{2}$ pollution. 


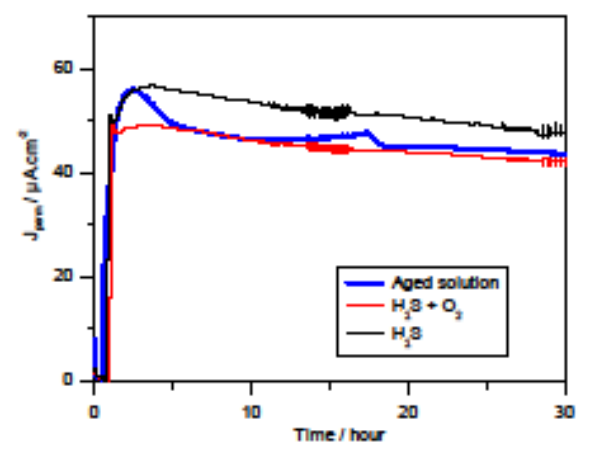

\section{Figure 13}

FIGURE 13. Hydrogen permeation transient with a test solution obtained after 3 weeks ageing with $\mathrm{H}_{2} \mathrm{~S}$ and $\mathrm{O}_{2}$ bubbling in presence of iron. Comparisons with a reference test with a fresh solution are included.

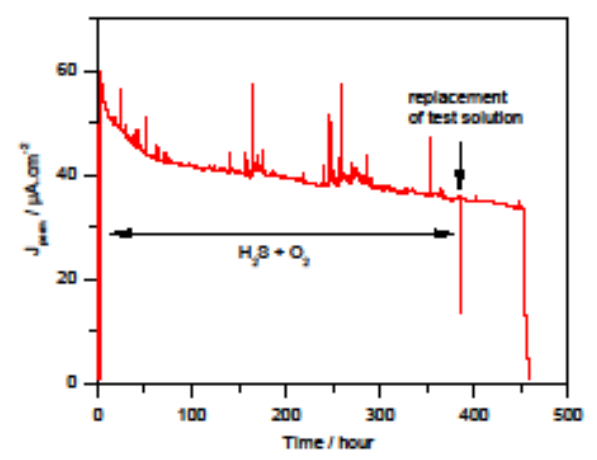

Figure 14

FIGURE 14. The Impact of introducing a freshly prepared, oxygen-polluted $\mathrm{H}_{2} \mathrm{~S}$-saturated solution (at $380 \mathrm{~h}$ ) on the hydrogen permeation across pure iron. 
